\title{
Psicoterapia em ambulatório de saúde do trabalhador: possibilidades e desafios
}

\section{Psychotherapy at workers' health clinics: possibilities and challenges}

\author{
Carla Júlia Segre Faiman
}

Faiman, CJS. Psicoterapia em ambulatório de saúde do trabalhador: possibilidades e desafios. São Paulo, 2012. 110p. Tese (Doutorado). Instituto de Psicologia, Universidade de São Paulo. Saúde, Ética \& Justiça. 2012;17(1):43.

RESUMO: Esta tese tem como proposta o estudo das possibilidades e das limitações da psicoterapia realizada em ambulatórios de saúde do trabalhador. Algumas questões são peculiares à atuação nesse tipo de ambulatório que, além de oferecer tratamento, assume a função de emitir relatórios em que constam diagnósticos, avaliações de capacidade laboral e o estabelecimento de relação causal entre trabalho e adoecimento. Esses relatórios servem de base para as avaliações periciais referentes à concessão de benefícios previdenciários. Para analisar as possibilidades e as dificuldades de psicoterapias no contexto em questão, são discutidos aspectos como a incidência de questões previdenciárias na demanda de atendimento, as relações entre sofrimento, adoecimento e afastamento do trabalho e a comunicação na equipe de saúde. Na busca de uma definição do campo de ação do psicoterapeuta nesses ambulatórios, propõe-se que não deve caber a este profissional a emissão de documentos com a aferição da capacidade laboral de seus pacientes de forma a contribuir ou a dificultar a obtenção de benefícios previdenciários. Discutem-se, também, questões relativas ao manejo da psicoterapia frente à queixa de violência relacionada ao trabalho. Cabe ao psicoterapeuta levar em consideração a importância que fatores relacionados ao contexto sócioeconômico e ao mundo do trabalho desempenham na vida de seus pacientes. No entanto, para que se desenvolva uma psicoterapia efetiva, é importante que o profissional delimite o campo de ação de seu atendimento, que é o âmbito da subjetividade do paciente. A psicoterapia tem como objetivo colaborar no desenvolvimento dos recursos pessoais que o trabalhador/paciente possa dispor para transformar a sua realidade.

DESCRITORES: Psicoterapia; Saúde do trabalhador; Psicologia clínica; Saúde ocupacional.

Faiman, CJS. Psychotherapy at workers' health clinics: possibilities and challenges. São Paulo, 2012. 110p. Tese (Doutorado). Instituto de Psicologia, Universidade de São Paulo. Saúde, Ética \& Justiça. 2012;17(1):43.

ABSTRACT: This thesis is proposed to investigate the possibilities and limitations of psychotherapy performed at workers' health clinics. Some issues are peculiar to this context of clinics in which, besides providing treatment, doctors assume the function of issuing reports with listed diagnoses, work capability assessments and the establishment of a causal relationship between the job and the illness. In Brazil these reports form a basis for the expertise evaluation concerning the granting of welfare benefits. To analyze the possibilities and difficulties of psychotherapy in the given context, we discuss aspects such as the incidence of social security issues in the demand for health care, the relationship among suffering, illness and sick-leave as well as the communication within the health team. In search of a definition for the psychotherapy action field, it is proposed that the psychotherapist should not be responsible for the issuance of documents reporting the work capability assessment of his patients, contributing to or hindering the achievement of social security benefits. We also discuss the management of psychotherapy regarding complaints of work-related violence issues. The psychotherapist must consider the importance that factors related to work and social-economic situation have in his patients' lives. However, in order to develop an effective psychotherapy, it is important that the professional delimit his field of action, which is the scope of the patient's subjectivity. Psychotherapy aims to collaborate on the development of personal resources that the workers / patients may have in order to transform their reality.

KEY WORDS: Psychotherapy; Occupational health; Clinical psychology; Workers' health. 